To the Editors:

\title{
Margosa (Kohomba) oil induced toxic encephalopathy following home remedy for intestinal worms
}

(Index words: margosa, encephalopathy, helminth infections)

Margosa oil induced toxic encephalopathy is a recognised entity [1]. It presents with vomiting which begins minutes to hours after ingestion, followed by drowsiness and generalised seizures. Hepatomegaly, elevated liver enzymes, metabolic acidosis and leukocytosis resembling Reye-like illness occur in children following margosa oil ingestion [2, 3]. The majority recover completely with symptomatic treatment with anticonvulsants and intravenous bicarbonate, but fatalities have been reported. Autopsy findings are fatty infiltration of the liver with mitochondrial damage and cerebral oedema [4].

A previously healthy 14-month old male infant presented to the Emergency Treatment Unit of the Lady Ridgeway Children's Hospital, Colombo, with an afebrile generalised tonic clonic seizure, lasting an hour. Intravenous diazepam and phenobarbitone achieved seizure control, but he had a respiratory arrest and was comatose for two to three hours. There was no meningeal irritation or localising signs, the pupils were equal in size and reactive, but plantars were up-going. The blood glucose was $9.1 \mathrm{mmol} / \mathrm{l}$. The child had been given a teaspoon of "kohomba oil" for deworming by his grandmother. This was the first time he had been given Kohomba (Margosa) oil. Vomiting and drowsiness followed by prolonged seizures had developed three hours after ingestion. There was no preceding history of trauma, ingestion of any other drug or seizure disorder in either him or his family. He regained consciousness a few hours after control of seizures.

Physical examination 24 hours later found him to be conscious, alert and neurologically normal. The only abnormal finding was hepatomegaly $3 \mathrm{~cm}$ below the costal margin. Investigation results were: white cell count $13.3 \times 10^{9} / 1$ with $83 \%$ lymphocytes, SGPT 120 IU/l (normal $<40$ ), prothrombin time $9.7 \mathrm{sec}$, blood urea $5.6 \mathrm{mmol} / \mathrm{l}$ and serum sodium $132 \mathrm{mmol} / \mathrm{l}$ and potassium $4.0 \mathrm{mmol} / \mathrm{l}$. Ultrasound examination showed an enlarged liver with coarse echogenicity. Electroencephalography 24 hours after the seizure was normal. He did not have a metabolic acidosis on blood gas analysis which was carried out 24 hours after recovery. When reviewed one month later, the hepatomegaly had resolved completely, SGPT was 16 IU/l (normal $<40$ ) and the liver architecture was ultrasonically normal.

Kohomba (Margosa) oil is the extract from the seed of the kohomba (neem) tree (Azadirachta indica). Its strong odour and bitter taste are due to volatile sulphur compounds and toxic fatty acids (nimbin, nimbinin, nimbidin and nimbidiol) [5]. In many Asian countries, including Sri Lanka, external application of this oil has been a commonly used traditional remedy. Sometimes, children are given small quantities orally. Toxic encephalopathy following ingestion of margosa oil is reported in infants and young children. One previous case has been reported in Sri Lanka [6].

Although a history of ingesting margosa oil was forthcoming no significance had initially been attached to it. Greater awareness is necessary regarding this potentially dangerous medicinal oil which is freely available and used widely and we recommend its inclusion in the book on poisoning issued by the National Poisons Information Centre of Sri Lanka.

\section{References}

1 Lai SM, Lim KW, Cheng HK. Margosa oil poisoning as a cause of toxic encephalopathy. Singapore Medical Journal 1990; 31: 463-5.

2 Sinniah D, Baskaran G. Margosa oil poisoning as a cause of Reye syndrome. Lancet 1981; 1: 487-9.

3 Sinniah D, Mitchell R. Margosa oil and Reye syndrome. Acta Paediatrica 1986; 28: 656-62.

4 Sinniah D, Baskaran G, Looi LM. Reye like syndrome due to Margosa oil poisoning: report of a case with post-mortem findings. American Journal of Gastroenterology 1982; 77: $158-61$.

5 Mitra C, Rao PN, Siddiqui S. Chemical examination of the root, bark of neem (Azadirachta indica= Melia azadirachta). Journal of Scientific Industrial Research 1953; 12B: 52-3.

6 Sri Ranganathan S, Fernandopulle R, Abeywardena BVDSP, et al. Kohomba oil induced encephalopathy: lessons in prescribing traditional medicines. Sri Lanka Journal of Child Health 2005; 34: 94-5.

\section{P Senanayake ${ }^{1}$, S Rupasinghe ${ }^{2}$, P V Dissanayake ${ }^{3}$ \\ ${ }^{1}$ Lady Ridgeway Hospital, Colombo, ${ }^{2}$ Department of Paediatrics, Faculty of Medicine, University of Colombo, Sri Lanka.}

Correspondence: MPS, e-mail <manouri.senanayake@gmail.com>. Received 30 March 2009 and revised version accepted 16 July 2009. Competing interests: none declared. 